\title{
PERBANDINGAN STRUKTUR MODAL INDUSTRI DASAR KIMIA DAN INDUSTRI BARANG KONSUMSI DI BEI
}

\author{
Rema Setyawati', Yuli Chomsatu², Anita Wijayanti3 \\ Fakultas Ekonomi Universitas Islam Batik Surakarta ${ }^{1,2,3}$
}

watiremao8@gmail.com';you.lichoms@gmail.com²; 3 itax solo@yahoo.com3

\begin{abstract}
ABSTRAK
Penelitian ini bertujuan untuk menganalisis dan membandingkan faktorfaktor yang mempengaruhi struktur modal pada perusahaan sektor industri dasar kimia dan perusahaan sektor industri barang konsumsi di BEI periode 204-2018. Metode yang digunakan dalam penelitian ini adalah regresi linier berganda. Hasil penelitian menunjukkan bahwa variabel likuiditas, struktur aset, ukuran perusahaan berpengaruh terhadap struktur modal perusahaan sektor industri dasar kimia. Profitabilitas dan pertumbuhan penjualan tidak berpengaruh terhadap struktur modal perusahaan sektor industri dasar kimia. Variabel likuiditas berpengaruh terhadap struktur modal perusahaan sektor industri barang konsumsi. Profitabilitas, struktur modal, ukuran perusahaan, pertumbuhan penjualan tidak berpengaruh terhadap struktur modal perusahaan sektor industri dasar barang konsumsi. Penelitian ini diharapkan mampu memberikan gambaran terhadap manajemen perusahaan atas faktor-faktor yang penting untuk dipertimbangkan dalam mengambil keputusan atas struktur modal perusahaan dan membantu para investor dalam menilai perusahaan dengan tepat agar tidak terjadi kesalahan saat dilakukannya penawaran saham dan dapat memberikan informasi mengenai kondisi keuangan suatu perusahaan sehingga mampu membantu calon investor dalam pengambilan keputasan investasi.
\end{abstract}

Kata Kunci : ROA, CR, SA, FS, GS, DER.

Abstract

This study aims to analyze and compare the factors that influence the capital structure of the basic chemical industry sector companies and the consumer goods industry sector companies on the IDX for the period 204-2018. The method used in this research is multiple linear regression. The results showed that the variable liquidity, asset structure, company size had an effect on the capital structure of companies in the basic chemical industry sector. Profitability and sales growth have no effect on the capital structure of companies in the basic chemical industry sector. The liquidity variable affects the capital structure of companies in the consumer goods industry sector. Profitability, capital structure, firm size, sales growth do not affect the capital structure of companies in the basic industrial sector of consumer goods. This research is expected to be able to provide an overview of company management on important factors to consider in making decisions on the company's capital structure and assist investors in assessing the company appropriately so that there are no mistakes when making a stock offering and can provide information about the financial condition of a company so as to be able to assist potential investors in making investment decisions.

Keywords : ROA, CR, SA, FS, GS, DER. 
Diterima: 23 Januari 2021; Direvisi: 30 Maret 2021; Diterbitkan: 10 April 2021

\section{PENDAHULUAN}

Di tengah perkembangan dunia yang semakin cepat, suatu negara dituntut untuk mampu menghadapi dan menyikapi perkembangan tersebut dengan cepat dan tepat. Suatu negara memiliki beberapa sektor perusahaan yang rentan terhadap perkembangan yang ada di dunia. Salah satu sektor tersebut adalah sektor perekonomian karena perekonomian merupakan sektor penting untuk keberlangsungan perkembangan suatu negara.

Salah satu cara untuk mempertahankan perusahaan adalah dengan cara mengembangkan ussaha di segala bidang. Indonesia adalah salah satu negara yang memiliki berbagai perusahaan yang semakin meningkat untuk memenuhi kebutuhan masyarakat. Sehingga perusahaan dari berbagai sektor saling bersaing untuk memenuhi pangsa pasar yang menuntut pendistribusian produk yang lebih cepat dan produk yang bervariasi agar bisa tetap bersaing dan sebagai pengembangan perusahaan. Dalam proses pengembangan perusahaan tentu membutuhkan tambahan pendanaan atau modal dalam bentuk uang atau ekuitas. Pendanaan bisa bersumber dari perusahaan seperti laba ditahan dan pendanaan dari luar perusahaan seperti hutang dari bank atau menerbitkan ekuitas.

Manajer harus mampu menghimpun dana baik yang bersumber dari dalam perusahaan maupun luar perusahaan secara efisien, yang berarti keputusan pendanaan tersebut merupakan keputusan yang mampu meminimalkan biaya modal yang harus ditanggung perusahaan. Biaya modal yang timbul dari keputusan pendanaan tersebut merupakan yang secara langsung timbul dari keputusan yang dilakukan manajer.

Struktur modal adalah komposisi saham biasa, saham preferen dan berbagai kelas seperti itu, laba yang ditahan dan hutang jangka panjang yang dipertahankan oleh kesatuan usaha dalam mendanai aktiva Fahmi (2015). Keputusan struktur modal secara langsung berpengaruh terhadap besarnya resiko yang ditanggung pemegang saham beserta besarnya tingkat-pengembalian atau tingkat keuntungan yang diharapkan

Brigham (2003). Tujuan dari penelitian ini diantaranya untuk menganalisis dan membandingkan faktor-faktor yang mempengaruhi struktur modal pada perusahaan sektor industri dasar kimia dan perusahaan sektor industri barang konsumsi di BEI.

\section{LANDASAN TEORI}

\section{Teori Sinyal}

Teori ini menjelaskan bahwa laporan keuangan yang baik merupakan sinyal atau tanda bahwa perusahaan juga telah beroperasi dengan baik. Respon pasar terhadap perusahaan sangat bergantung pada sinyal yang dikeluarkan oleh perusahaan. Sinyal yang dimaksud merupakan kaitannya dengan informasi, sebagai pengungkapan yang dilakukan perusahaan dalam laporan tahunan. Semakin tinggi profit yang diperoleh suatu perusahaan maka nilai perusahaan juga semakin tinggi karena diminati oleh para investor.

Laporan lanjutan digunakan oleh manajer sebagai sinyal profitabilitas perusahaan kepada para 
investor dan untuk mendukung dan kompensasi sehingga perusahaan yang lebih baik akan semakin terbuka dan transparan dalam melaporkan informasi tentang perusahaannya Megginson (1987).

\section{Struktur Modal}

Struktur modal perusahaan merupakan salah satu faktor fundamental dalam operasi perusahaan. Struktur modal suatu perusahaan oleh manajer keuangan dalam mengambil kebijakan pembelanjaan yang baik secara kualitatif maupun kuantitatif (Utami L, 2013). (Soehardi et al., 2020)

Struktur

perusahaan merupakan pendanaan yang dilakukan oleh manajer keuangan yang berkaitan dengan bagaimana membiayai keputusan investasi yang akan dilakukan perusahaan (Irza Nofriani, 2015). Dihitung dengan rumus sebagai berikut:

$$
\text { DER }=\frac{\text { Total Hutang }}{\text { Total Ekuitas }} \times 100 \%
$$

\section{Profitabilitas}

Rasio profitabilitas dapat diukur dengan cara membandingkan antara laba bersih setelah pajak dengan total aktiva atau modal. Modal perusahaan berasal dari pemilik perusahaan (modal sendiri) Munawir (2012). Pada umumnya perusahaan lebih suka jika pendapatan yang mereka terima digunakan sebagai sumber utama untuk melakukan pembiayaan investasi. (2013)

Menurut Brigham dan Houston profitabilitas adalah kemampuan perusahaan

memperoleh laba melalui operasionalnya menggunakan dana aset yang dimiliki perusahaan tersebut. Untuk menghitung profitabilitas menggunakan rumus:

$$
\mathrm{ROA}=\frac{\text { Laba Bersih }}{\text { Total Aset }} \times 100 \%
$$

\section{Likuiditas}

Likuiditas merupakan salah satu faktor yang diperhitungkan dalam keputusan struktur modal. Menurut Riyanto B (2001), likuiditas perusahaan adalah kemampuan sebuah perusahaan memenuhi kewajiban jangka pendeknya. Kemampuan tersebut merupakan kemampuan perusahaan untuk melanjutkan operasionalnya ketika perusahaan tersebut diwajibkan untuk melunasi kewajibannya yang akan mengurangi dana operasionalnya.

Likuiditas

merupakan

kemampuan untuk mengubah aktiva menjadikan kas atau kemampuan unruk memperoleh kas. Untuk menghitung likuiditas menggunakan rumus:

$$
C R=\frac{\text { Aktiva Lancar }}{\text { Hutang Lancar }} \times 100 \%
$$

\section{Struktur Aset}

Menurut Sari dan Haryanto (2013: 6) dalam (Irza Nofriani, 2015), struktur aset dapat digunakan oleh perusahaan sebagai jaminan untuk mendapatkan utang. Perusahaan yang memiliki aset tetap yang banyak dan bernilai tinggi, perusahaan dapat memanfaatkan aset tersebut untuk mendapatkan modal tambahan dari luar perusahaan 
atau external financing yaitu melalui hutang Sitanggang (2013).

Struktur aset menggambarkan besarnya aktiva yang dapat dijaminkan perusahaan ketika melakukan pinjaman kepada pihak kreditur. Untuk menghitung struktur aset menggunkan rumus:

$$
\text { Struktur Aset }=\frac{\text { Aset Tetap }}{\text { Total Aset }} \times 100 \%
$$

\section{Ukuran Perusahaan}

Ukuran perusahaan dapat diartikan sebagai besar kecilnya perusahaan dilihat dari besarnya nilai ekuitas perusahaan, ataupun hasil nilai total aktiva dari suaru perusahaan Riyanto (2001). Ukuran perusahaan yang tinggi berarti perusahaan tersebut akan lebih mudah mengakses modal di pasar modal dan kecenderungan untuk menggunakan jumlah pinjaman juga semakin besar pula.

Semakin besar ukuran perusahaan semakin mudah untuk mendapatkan modal eksternal dalam jumlah yang lebih besar terutama dari hutang. Diikuti dengan ukuran perusahaan dimana semakin besar skala ukuran perusahaan maka profitabilitas juga akan meningkat (Barus, 2013).

Ukuran perusahaan merupakan nilai yang menunjukkan besar kecilnya perusahaan. Untuk mengukur ukuran perusahaan menggunakan rumus:

$$
\text { Ukuran Perusahaan }=\operatorname{Ln}(\text { Total Aset })
$$

\section{Pertumbuhan Penjualan}

Pertumbuhan penjualan merupakan ukuran mengenai besarnya pendapatan perusahaan. merupakan selisih antara jumlah penjualan periode sekarang dengan periode sebelumnya dibandingkan dengan periode sebelumnya Harahap (2008).

Pertumbuhan penjualan yang merupakan jumlah penjualan periode sekrang dengan periode sebelumnya dibandingkan dengan periode sebelumnya. Untuk mengukur pertumbuhan penjualan menggunakan rumus:

$$
\text { Growth Sales }=\frac{\text { Sales }_{t}-\text { Sales }_{t-1}}{\text { Sales }_{t-1}}
$$

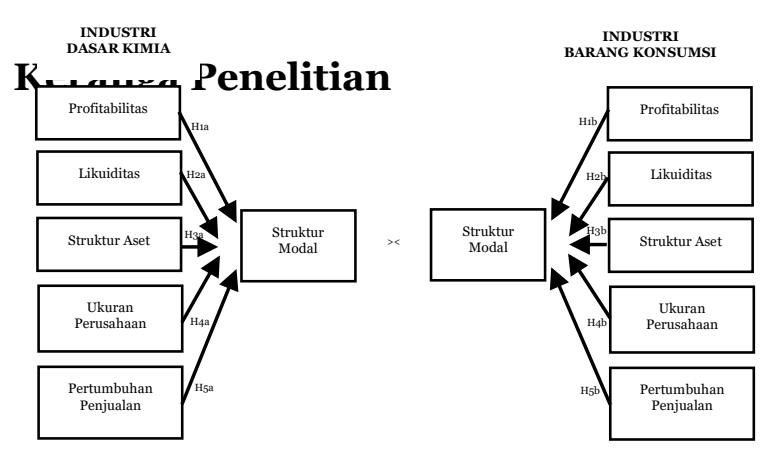

\section{Hipotesis}

H1a : Profitabilitas berpengaruh terhadap struktur modal industri dasar kimia;

H1b : Profitabilitas berpengaruh terhadap struktur modal industri barang konsumsi;

H2a : Likuiditas berpengaruh terhadap struktur modal industri dasar kimia;

H2b : Likuiditas berpengaruh terhadap struktur modal industri barang konsumsi;

H3a : Struktur aset berpengaruh terhadap struktur modal industri dasar kimia;

$\mathrm{H} 3 \mathrm{~b}$ : Struktur aset berpengaruh terhadap struktur modal industri barang konsumsi; 
H4a : Ukuran perusahaan berpengaruh terhadap struktur modal industri dasar kimia;

H4b : Ukuran perusahaan berpengaruh terhadap struktur modal industri barang konsumsi;

H5a : Pertumbuhan penjuaan berpengaruh terhadap struktur modal industri dasar kimia;

$\mathrm{H}_{5} \mathrm{~b}$ : Pertumbuhan penjuaan berpengaruh terhadap struktur modal industri barang konsumsi.

\section{METODE PENELITIAN}

Metode penelitian ini adalah penelitian kuantitatif dengan analisis regresi linier berganda. Pengolahan data menggunakan software SPSS versi 25. Populasi yang digunakan dalam penelitian ini adalah perusahaan sektor industri dasar kimia dan perusahaan sektor industri barang konsumsi yang terdaftar di Bursa Efek Indonesia (BEI) tahun 20142018. Data yang digunakan dalam penelitian ini adalah data sekunder yang berupa laporan keuangan tahunan (annual report) perusahaan yang diambil dari situs resmi Bursa Efek Indonesia, yaitu www.idx.co.id. Kriteria sampel ditentukan dengan purposive sampling. Dari kriteria yang ditentukan didapat sampel sebanyak 235 data perusahaan selama tahun 2014-2018.

\section{HASIL PENELITIAN PEMBAHASAN}

DAN

Berdasarkan kriteria penentuan sampel yang telah dibahas pada bab sebelumnya, sampel diperoleh dengan rincian sebagai berikut:

Tabel 1 Kriteria Penuntuan Sampel

\begin{tabular}{|c|c|}
\hline Kriteria Pengambilan Sampel & $\begin{array}{c}\text { Jumlah } \\
\text { Perusahaan }\end{array}$ \\
\hline $\begin{array}{l}\text { Perusahaan sektor } \\
\text { industri dasar kimia dan } \\
\text { perusahaan sektor } \\
\text { industri } \\
\text { barang konsumsi } \\
\text { yang terdaftar di Bursa } \\
\text { Efek Indonesia (BEI) } \\
\text { selama tahun 2014-2018 }\end{array}$ & 137 \\
\hline $\begin{array}{l}\text { 2. Perusahaan } \\
\begin{array}{l}\text { delisting selama 2014- } \\
2018\end{array}\end{array}$ & (o) \\
\hline $\begin{array}{l}\text { Perusahaan dasar kimia } \\
\text { dan perusahaan barang } \\
\text { konsumsi yang memiliki } \\
\text { data tidak lengkap }\end{array}$ & (54) \\
\hline $\begin{array}{l}\text { 4. Perusahaan yang tidak } \\
\text { menggunakan mata uang } \\
\text { Rupiah }\end{array}$ & (3) \\
\hline 5. $\begin{array}{lr}\text { Perusahaan } & \text { yang } \\
\text { mengalami } & \text { kerugian } \\
\text { selama tahun } & \text { 2014-2018 }\end{array}$ & (33) \\
\hline $\begin{array}{l}\text { Jumlah perusahaan yang } \\
\text { menjadi sampel }\end{array}$ & 47 \\
\hline $\begin{array}{l}\text { Jumlah data selama lima } \\
\text { tahun }\end{array}$ & 235 \\
\hline Outlier & (32) \\
\hline Total Data Yang Diolah & $\mathbf{2 0 3}$ \\
\hline \multicolumn{2}{|c|}{ Sumber: Data diolah oleh Peneliti, (2021) } \\
\hline \multicolumn{2}{|l|}{ Uji Asumsi Klasik } \\
\hline \multicolumn{2}{|l|}{ Hasil Uji Normalitas } \\
\hline \multicolumn{2}{|c|}{$\begin{array}{l}\text { menguji apakah dalam model regresi, } \\
\text { variabel residual memiliki distribusi } \\
\text { normal. Hasil uji Normalitas disajikan } \\
\text { dalam tabel sebagai berikut: }\end{array}$} \\
\hline \multicolumn{2}{|c|}{ Tabel 2 Hasil Uji Normalitas } \\
\hline $\begin{array}{l}\text { Unstan } \\
\text { dardize } \\
\quad \text { d } \\
\text { Residua }\end{array}$ & $\begin{array}{l}\text { Keterang } \\
\text { an }\end{array}$ \\
\hline
\end{tabular}




\begin{tabular}{lccc}
\hline & $\mathbf{l}$ & & \\
\hline $\begin{array}{l}\text { Asymp. } \\
\text { Sig. (2- } \\
\text { tailed) }\end{array}$ & 0,200 & $\begin{array}{c}\text { Data } \\
\end{array}$ & $\begin{array}{c}\text { Terdistrib } \\
\text { usi } \\
\text { Normal }\end{array}$ \\
\hline & Industri Barang Konsumsi \\
\hline & $\begin{array}{c}\text { Unstandardize } \\
\text { d Residual }\end{array}$ & $\begin{array}{c}\text { Sta } \\
\text { nda } \\
\text { r }\end{array}$ & $\begin{array}{c}\text { Keterang } \\
\text { an }\end{array}$ \\
\hline $\begin{array}{l}\text { Asymp. } \\
\text { Sig. (2- } \\
\text { tailed) }\end{array}$ & 0,200 & $>$ & $\begin{array}{c}\text { Data } \\
\text { Terdistrib } \\
\text { usi } \\
\text { Normal }\end{array}$ \\
\hline
\end{tabular}

\begin{tabular}{ccc}
\hline $\begin{array}{c}\text { Sig. (2- } \\
\text { tailed) }\end{array}$ & Standar & Kesimpulan \\
\hline 0,873 & $>0,05$ & Data terdistribusi normal \\
\hline
\end{tabular}

Sumber : Pengolahan Data SPSS, (2021)

Berdasarkan hasil uji normalitas pada tabel 2 industri dasar kimia dan industri barang konsumsi menunjukkan bahwa Unstandardized Residual dari uji One-Sample KolmogorovSmirnov Test memiliki nilai >0,05. Hal ini dapat disimpulkan bahwa data berdistribusi normal.

\section{Hasil Uji Multikolinieritas}

untuk

Uji Multikolinearitas

apakah model regresi

bertujuan menguji ditemukan adanya korelasi antar variabel bebas. Hasil uji multikolinearitas disajikan dalam tabel sebagai berikut:

Tabel 3 Hasil Uji Multikolinieritas

\begin{tabular}{|c|c|c|c|c|c|}
\hline \multicolumn{6}{|c|}{ Industri Dasar Kimia } \\
\hline Model & $\begin{array}{c}\text { Tol } \\
\text { era } \\
\text { nc } \\
\boldsymbol{e}\end{array}$ & $\begin{array}{l}\text { Sta } \\
\text { nd }\end{array}$ & $\begin{array}{l}\text { VI } \\
\text { F }\end{array}$ & $\begin{array}{l}\text { Sta } \\
\text { nd }\end{array}$ & Keterangan \\
\hline ROA & $\begin{array}{c}0 \\
94 \\
9\end{array}$ & $\begin{array}{c}>0 \\
1\end{array}$ & $\begin{array}{c}1, \\
\text { O5 } \\
3\end{array}$ & $<10$ & $\begin{array}{l}\text { Tidak terjadi } \\
\text { multikolinearit } \\
\text { as }\end{array}$ \\
\hline CR & $\begin{array}{c}0 \\
72 \\
4\end{array}$ & $\begin{array}{c}>0, \\
1\end{array}$ & $\begin{array}{c}1, \\
38 \\
1\end{array}$ & $<10$ & $\begin{array}{l}\text { Tidak terjadi } \\
\text { multikolinearit } \\
\text { as }\end{array}$ \\
\hline SA & $\begin{array}{c}0 \\
78 \\
1\end{array}$ & $\begin{array}{c}>0 \\
1\end{array}$ & $\begin{array}{c}1, \\
28 \\
1\end{array}$ & $<10$ & $\begin{array}{l}\text { Tidak terjadi } \\
\text { multikolinearit } \\
\text { as }\end{array}$ \\
\hline FS & 0,9 & $>0$, & 1,0 & $<10$ & Tidak terjadi \\
\hline
\end{tabular}

\begin{tabular}{|c|c|c|c|c|c|}
\hline GS & $\begin{array}{c}0,8 \\
94\end{array}$ & $\begin{array}{c}>0 \\
1\end{array}$ & $\begin{array}{c}1,11 \\
8\end{array}$ & $<10$ & $\begin{array}{l}\text { multikolinearit } \\
\text { as } \\
\text { Tidak terjadi } \\
\text { multikolinearit } \\
\text { as }\end{array}$ \\
\hline \multicolumn{6}{|c|}{ Industri Barang Konsumsi } \\
\hline Model & $\begin{array}{c}\text { Tol } \\
\text { era } \\
\text { nc } \\
e\end{array}$ & $\begin{array}{l}\text { Sta } \\
\text { nd }\end{array}$ & $\begin{array}{c}\text { VI } \\
\text { F }\end{array}$ & $\begin{array}{l}\text { Sta } \\
\text { nd }\end{array}$ & Keterangan \\
\hline ROA & $\begin{array}{l}0, \\
82 \\
8\end{array}$ & $\begin{array}{c}>0 \\
1\end{array}$ & $\begin{array}{l}1 \\
2 \\
0 \\
8\end{array}$ & $<10$ & $\begin{array}{l}\text { Tidak terjadi } \\
\text { multikolinearit } \\
\text { as }\end{array}$ \\
\hline CR & $\begin{array}{c}0, \\
83 \\
6\end{array}$ & $\begin{array}{c}>0 \\
1\end{array}$ & $\begin{array}{l}1,1 \\
96\end{array}$ & $<10$ & $\begin{array}{l}\text { Tidak terjadi } \\
\text { multikolinearit } \\
\text { as }\end{array}$ \\
\hline SA & $\begin{array}{l}0 \\
8 \\
8 \\
4\end{array}$ & $\begin{array}{c}>0 \\
1\end{array}$ & $\begin{array}{l}1,1 \\
31\end{array}$ & $<10$ & $\begin{array}{l}\text { Tidak terjadi } \\
\text { multikolinearit } \\
\text { as }\end{array}$ \\
\hline FS & $\begin{array}{l}0,9 \\
08\end{array}$ & $\begin{array}{c}>0 \\
1\end{array}$ & $\begin{array}{c}1,10 \\
1\end{array}$ & $<10$ & $\begin{array}{l}\text { Tidak terjadi } \\
\text { multikolinearit } \\
\text { as }\end{array}$ \\
\hline GS & $\begin{array}{c}0,9 \\
46\end{array}$ & $\begin{array}{c}>0 \\
1\end{array}$ & $\begin{array}{l}1,0 \\
57\end{array}$ & $<10$ & $\begin{array}{l}\text { Tidak terjadi } \\
\text { multikolinearit } \\
\text { as }\end{array}$ \\
\hline
\end{tabular}

Sumber : Pengolahan Data SPSS, (2021)

Pada tabel 3 menunjukkan bahwa variabel profitabilitas (ROA), likuiditas (CR), struktur aset (SA), ukuran perusahaan (FS), pertumbuhan penjualan (GS) pada industri dasar kimia dan industri barang konsumsi memiliki nilai tolerance $>0,01$ dan nilai VIF < 10 sehingga dapat dikatakan tidak terjadi multi kolinearitas.

\section{Hasil Uji Autokorelasi}

Uji autokorelasi digunakan untuk mengetahui ada atau tidaknya penyimpangan asumsi klasik autokorelas i yaitu korelasi yang terjadi antara residual pada satu pengamatan model regresi. Hasil uji autokorelasi disajikan dalam tabel sebagai berikut:

Tabel 4 Hasil Uji Autokorelasi Industri Dasar Kimia

Model $\mathrm{dU}<\mathrm{Dw} \quad<4^{-} \quad$ Keterangan




\begin{tabular}{ccccc}
\hline & \multicolumn{4}{c}{$\mathrm{dU}$} \\
\hline 1 & $\begin{array}{c}1,785 \\
<\end{array}$ & 2,023 & $\begin{array}{c}< \\
2,215\end{array}$ & $\begin{array}{c}\text { Tidak terjadi } \\
\text { autokorelasi }\end{array}$ \\
\hline \multicolumn{5}{c}{ Industri Barang Konsumsi } \\
\hline Model & $\mathrm{dU}<$ & $\mathrm{Dw}$ & $\begin{array}{c}<- \\
\mathrm{dU}\end{array}$ & Keterangan \\
\hline \multirow{2}{*}{1} & $\begin{array}{c}1,7776 \\
<\end{array}$ & 1,888 & $\begin{array}{c}< \\
2,2224\end{array}$ & $\begin{array}{c}\text { Tidak Terjadi } \\
\text { Autokorelasi }\end{array}$
\end{tabular}

Sumber : Pengolahan Data SPSS (2021)

Pada tabel 4 menunjukan industri dasar kimia dan industri barang konsumsi memiliki nilai DurbinWatson > dU dan < 4-dU sehingga dapat disimpulkan bahwa tidak terjadi autokorelasi.

\section{Hasil Uji Heteroskedastisitas}

Uji Heteroskedastisitas bertujuan untuk menguji apakah nilai dalam model regresi terjadi ketidaksamaan variance residual satu pengamatan ke pengamatan yang lain. Hasil uji Heteroskedastisitas disajikan dalam tabel sebagai berikut:

Tabel 5 Hasil Uji Heteroskedastisitas

\begin{tabular}{|c|c|c|c|}
\hline \multicolumn{4}{|c|}{ Industri Dasar Kimia } \\
\hline Model & Sig. & Standar & Keterangan \\
\hline ROA & 0,576 & $>0,05$ & $\begin{array}{c}\text { Tidak terjadi } \\
\text { Heteroskedastisitas } \\
\text { Tidak terjadi }\end{array}$ \\
\hline CR & 0,052 & $>0,05$ & $\begin{array}{l}\text { Heteroskedastisitas } \\
\text { Tidak terjadi }\end{array}$ \\
\hline SA & 0,346 & $>0,05$ & $\begin{array}{l}\text { Heteroskedastisitas } \\
\text { Tidak terjadi }\end{array}$ \\
\hline FS & 0,313 & $>0,05$ & $\begin{array}{l}\text { Heteroskedastisitas } \\
\text { Tidak terjadi }\end{array}$ \\
\hline GS & 0,737 & $>0,05$ & Heteroskedastisitas \\
\hline \multicolumn{4}{|c|}{ Industri Barang Konsumsi } \\
\hline Model & Sig. & Standar & Keterangan \\
\hline ROA & 0,778 & $>0,05$ & $\begin{array}{c}\text { Tidak terjadi } \\
\text { Heteroskedastisitas }\end{array}$ \\
\hline CR & 0,727 & $>0,05$ & $\begin{array}{c}\text { Tidak terjadi } \\
\text { Heteroskedastisitas }\end{array}$ \\
\hline SA & 0,546 & $>0,05$ & $\begin{array}{c}\text { Tidak terjadi } \\
\text { Heteroskedastisitas }\end{array}$ \\
\hline FS & 0,658 & $>0,05$ & $\begin{array}{c}\text { Tidak terjadi } \\
\text { Heteroskedastisitas }\end{array}$ \\
\hline
\end{tabular}

GS $\quad 0,779>0,05 \quad$ Tidak terjadi

Sumber : Pengolahan Data SPSS (2021)

Berdasarkan tabel 5 variabel profitabilitas (ROA), likuiditas (CR), struktur aset (SA), ukuran perusahaan (FS), dan pertumbuhan penjualan (GS) pada industri dasar kimia dan industri barang konsumsi memiliki nilai >0,05. Sehingga dapat disimpulkan bahwa tidak terjadi heteroskedastisitas.

\section{Hasil Regresi Linier Berganda}

Tabel 6 Hasil Uji Analisis Regresi Linier Berganda Unstandardiz Unstandardiz ed Coefficients ed Coefficients

Variabel

B (Industri Dasar Kimia)

$\begin{array}{lcc}\text { (Constant) } & 3,561 & -0,017 \\ \text { Profitabilit } & -0,946 & -0,068 \\ \text { as } & -0,138 & -1,098 \\ \begin{array}{l}\text { Likuiditas } \\ \text { Struktur }\end{array} & -1,408 & 0,005 \\ \begin{array}{l}\text { Aset } \\ \text { Ukuran }\end{array} & -0,069 & 0,116 \\ \begin{array}{l}\text { Perusahaan } \\ \text { Pertumbuha }\end{array} & -0,786 & 0,068 \\ \text { n Penjualan } & & \end{array}$

Sumber : Pengolahan Data SPSS (2021)

Dari tabel 6 Dapat diketahi bentuk persamaan model regresi penelitian :

$\mathrm{Y} 1=3,561+(-0,946) \mathrm{ROA}+(-0,138) \mathrm{CR}$ $+(-1,408) \mathrm{SA}+(-0,069) \mathrm{FS}+(-0,786) \mathrm{GS}$

$\mathrm{Y} 2=-0,017+(-0,068) \mathrm{ROA}+(-1,098) \mathrm{CR}$ $+0,005 \mathrm{SA}+0,116 \mathrm{FS}+0,068 \mathrm{GS}$

Konstanta yang diperoleh industri dasar kimia sebesar 3,561 menunjukkan jika semua variabel independen bernilai o, maka struktur modal (DER) akan sebesar 3,561. Sedangkan konstanta yang diperoleh industri barang konsumsi sebesar -0.017 
menunjukkan jika semua variabel o, maka struktur modal (DER) akan sebesar o,017.

Koefisien regresi variabel profitabilit as (ROA) pada industri dasar kimia bernilai -0,946. Hal ini berarti apabila variabel profitabilitas (ROA) naik sebesar 1 persen dengan asumsi variabel lainnya tetap, maka akan menurunkan struktur modal sebesar 0,946. Koefisien regresi variabel profitabilitas (ROA) pada industri dasar kimia bernilai -0,068. Hal ini berarti apabila variabel profitabilitas (ROA) naik sebesar 1 persen dengan asumsi variabel lainnya tetap, maka akan menurunkan struktur modal sebesar o,068.

Koefisien regresi variabel struktur aset (SA) pada industri dasar kimia bernilai 1,408. Hal ini berarti apabila variabel struktur aset (SA) naik sebesar 1 persen dengan asumsi variabel lainnya tetap, maka akan menurunkan struktur modal sebesar 1,408. Koefisien regresi variabel struktur aset (SA) pada industri dasar kimia bernilai o,005. Hal ini berarti apabila variabel struktur aset (SA) naik sebesar 1 persen dengan asumsi variabel lainnya tetap, maka akan diikuti kenaikan struktur modal sebesar 0,005.

Koefisien regresi variabel ukuran perusahaan (FS) pada industri dasar kimia bernilai -0,069. Hal ini berarti apabila variabel ukuran perusahaan (FS) naik sebesar 1 persen dengan asumsi variabel lainnya tetap, maka akan menurunkan struktur modal sebesar 0,069. Koefisien regresi variabel ukuran perusahaan (FS) pada industri dasar kimia bernilai o,116. Hal ini berarti apabila ukuran perusahaan (FS) naik sebesar 1 persen dengan asumsi variabel lainnya tetap, maka akan diikuti kenaikan struktur modal sebesar 0,116.
Koefisien regresi variebl pertumbuhan penjualan (GS) pada industri dasar kimia bernilai $-0,786$. Hal ini berarti apabila variabel pertumbuhan penjualan (GS) naik sebesar 1 persen dengan asumsi variabel lainnya tetap, maka akan menurunkan struktur modal sebesar 0,786. Sedangkan koefisien regresi variabel pertumbuhan penjualan (GS) pada industri dasar kimia bernilai o,o68. Hal ini berarti apabila pertumbuhan penjualan (GS) naik sebesar 1 persen dengan asumsi variabel lainnya tetap, maka akan diikuti kenaikan struktur modal sebesar 0,068 .

\section{Hasil Uji Kelayakan Model}

\section{Hasil Uji F}

Tabel 7 Hasil Uji F

\begin{tabular}{cccccc}
\hline \multicolumn{6}{c}{ Industri Dasar Kimia } \\
\hline Model & $\mathrm{F}_{\text {hit }}$ & $\mathrm{F}_{\text {tabel }}$ & Sig. & Std. & Keterangan \\
& ung & & & & \\
\hline 1 & 14, & $>2,4$ & 0,0 & $<0,0$ & Model \\
& 346 & 6 & 0 & 5 & Layak \\
\hline \multicolumn{6}{c}{ Industri Barang } \\
\hline Model & F $_{\text {hit }}$ & F $_{\text {tabel }}$ & Sig. & Std. & Keterangan \\
& ung & & & & \\
\hline 1 & 94, & $>2,4$ & 0,0 & $<0,0$ & Model \\
& 058 & 8 & 0 & 5 & Layak \\
\hline
\end{tabular}

Sumber : Pengolahan Data SPSS (2021)

Berdasarkan tabel 7 pada industri dasar kimia diperoleh Fhitung sebesar 14,346 yang artinya $F_{\text {hitung }}>F_{\text {tabel }}(14,346>2,46)$ dan nilai signifikansi sebesar $0,00<0,005$. Pada industri dasar kimia diperoleh $\mathrm{F}_{\text {hitung }}$ sebesar 94,058 yang artinya $F_{\text {hitung }}>F_{\text {tabel }}$ $(14,346>2,48)$ dan nilai signifikansi sebesar $0,00<0,005$. Sehingga dapat disimpulakn bahwa secara simultan variabel profitabilitas, likuiditas, struktur aset, ukuran perusahaan, pertumbuhan penjualan berpengaruh terhadap variabel struktur modal perusahaan 
industri dasar kimia dan industri barang konsumsi.

\section{Hasil Uji Hipotesis (Uji t)}

Tabel 8 Hasil Uji Hipotesis

\begin{tabular}{|c|c|c|c|c|c|}
\hline $\begin{array}{l}\text { Hipo } \\
\text { tesis }\end{array}$ & $t_{\text {hitung }}$ & $\begin{array}{c}t_{\text {tabe }} \\
1\end{array}$ & Sig. & $\begin{array}{c}\text { Stan } \\
\text { dar }\end{array}$ & Keterangan \\
\hline $\begin{array}{l}\mathrm{H} 1 \mathrm{a} \\
\text { (ROA) }\end{array}$ & $\begin{array}{c}- \\
0,8 \\
01\end{array}$ & $\begin{array}{c}- \\
1,9 \\
83\end{array}$ & $\begin{array}{l}0,4 \\
25\end{array}$ & $<0,05$ & Ditolak \\
\hline $\begin{array}{l}\mathrm{H} 1 \mathrm{~b} \\
\text { (ROA) }\end{array}$ & $\begin{array}{c}- \\
1,61 \\
6\end{array}$ & $\begin{array}{c}- \\
1,9 \\
87\end{array}$ & $\begin{array}{c}0,11 \\
0\end{array}$ & $<0,05$ & Ditolak \\
\hline $\begin{array}{l}\mathrm{H} 2 \mathrm{a} \\
\text { (CR) }\end{array}$ & $\begin{array}{c}- \\
6,35 \\
4\end{array}$ & $\begin{array}{c}- \\
1,9 \\
83\end{array}$ & $\begin{array}{l}0,0 \\
00\end{array}$ & $<0,05$ & Diterima \\
\hline $\begin{array}{l}\text { H2b } \\
\text { (CR) }\end{array}$ & $\begin{array}{c}19,2 \\
43\end{array}$ & $\begin{array}{c}- \\
1,9 \\
87\end{array}$ & $\begin{array}{l}\text { O,O } \\
\text { oo }\end{array}$ & $<0,05$ & Diterima \\
\hline $\begin{array}{l}\mathrm{H}_{3 \mathrm{a}} \\
\text { (SA) }\end{array}$ & $\begin{array}{c}- \\
4,42 \\
8\end{array}$ & $\begin{array}{c}- \\
1,9 \\
83\end{array}$ & $\begin{array}{l}\text { o,o } \\
\text { oo }\end{array}$ & $<0,05$ & Diterima \\
\hline $\begin{array}{l}\mathrm{H}_{3} \mathrm{~b} \\
\text { (SA) }\end{array}$ & $\begin{array}{c}0,10 \\
1\end{array}$ & $\begin{array}{l}1,9 \\
87\end{array}$ & $\begin{array}{l}0,9 \\
20\end{array}$ & $<0,05$ & Ditolak \\
\hline $\begin{array}{l}\mathrm{H} 4 \mathrm{a} \\
\text { (FS) }\end{array}$ & $\begin{array}{c}- \\
5,45 \\
8\end{array}$ & $\begin{array}{c}- \\
1,9 \\
83\end{array}$ & $\begin{array}{l}\text { o,o } \\
\text { oo }\end{array}$ & $<0,05$ & Diterima \\
\hline $\begin{array}{l}\mathrm{H}_{4} \mathrm{~b} \\
\text { (FS) }\end{array}$ & $\begin{array}{c}0,95 \\
3\end{array}$ & $\begin{array}{l}1,9 \\
87\end{array}$ & $\begin{array}{c}0,3 \\
43\end{array}$ & $<0,05$ & Ditolak \\
\hline $\begin{array}{l}\mathrm{H}_{5 \mathrm{a}} \\
\text { (GS) }\end{array}$ & $\begin{array}{c}- \\
1,89 \\
3\end{array}$ & $\begin{array}{c}- \\
1,9 \\
83\end{array}$ & $\begin{array}{c}0,0 \\
61\end{array}$ & $<0,05$ & Ditolak \\
\hline $\begin{array}{l}\mathrm{H}_{5} \mathrm{~b} \\
\text { (GS) }\end{array}$ & $\begin{array}{c}1,59 \\
5\end{array}$ & $\begin{array}{l}1,9 \\
87\end{array}$ & $\begin{array}{c}0,11 \\
4\end{array}$ & $<0,05$ & Ditolak \\
\hline
\end{tabular}

Sumber : Pengolahan Data SPSS (2021)

Berdasarkan table 8, H1a dan $\mathrm{H} 1 \mathrm{~b}$ memiliki nilai $\mathbf{t}_{\text {hitung }}>\mathbf{t}_{\text {tabel }}$ dan nilai sig $>$ 0,05 sehingga dapat dikatakan H1a dan H1b tidak berpengaruh terhadap struktur modal.

H2a dan H2b memiliki nilai $\mathbf{t}_{\text {hitung }}<$ $\mathbf{t}_{\text {tabel }}$ dan nilai sig $<0,05$ sehingga dapat dikatakan H2a dan H2b berpengaruh terhadap struktur modal.

H3a memiliki nilai $\mathbf{t}_{\text {hitung }}<\mathbf{t}_{\text {tabel }}$ dan nilai sig $<0,05$ sehingga dapat dikatakan
H3a berpengaruh terhadap struktur modal. $\mathrm{H} 3 \mathrm{~b}$ memiliki nilai thitung $>\mathbf{t}_{\text {tabel }}$ dan nilai sig $>0,05$ sehingga dapat dikatakan H3b tidak berpengaruh terhadap struktur modal.

H4a memiliki nilai $\mathbf{t}_{\text {hitung }}<\mathbf{t}_{\text {tabel }}$ dan nilai sig $<0,05$ sehingga dapat dikatakan H4a berpengaruh terhadap struktur modal. H4b memiliki nilai $\mathbf{t}_{\text {hitung }}$ $>\mathbf{t}_{\text {tabel }}$ dan nilai sig $>0$,05 sehingga dapat dikatakan $\mathrm{H} 4 \mathrm{~b}$ tidak berpengaruh terhadap struktur modal.

$\mathrm{H}_{5}$ a dan $\mathrm{H}_{5} \mathrm{~b}$ memiliki nilai $\mathbf{t}_{\text {hitung }}>$

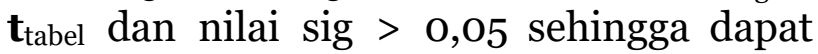
dikatakan H5a dan $\mathrm{H} 5 \mathrm{~b}$ tidak berpengaruh terhadap struktur modal.

\section{Hasil Uji Koefisien Determinasi (R2)}

Untuk mengukur seberapa besar peranan variabel independen secara bersama-sama menjelaskan perubahan yang terjadi pada variabel dependen. Hasil pengujian koefisien determinasi disajikan dalam tabel sebagai berikut:

Tabel 9 Hasil Uji Koefisien Determinasi

\begin{tabular}{|c|c|c|}
\hline \multicolumn{3}{|c|}{ Industri Dasar Kimia } \\
\hline Model & $\begin{array}{l}\text { Adjusted R } \\
\text { Square }\end{array}$ & Keterangan \\
\hline 1 & 0,382 & $\begin{array}{l}\text { Variabel profitabilitas, } \\
\text { likuiditas, struktur aset, } \\
\text { ukuran perusahaan, } \\
\text { pertumbuhan penjualan } \\
\text { berpengaruh terhadap } \\
\text { struktur modal sebesar } \\
38,2 \%\end{array}$ \\
\hline
\end{tabular}

\begin{tabular}{ccc}
\hline \multicolumn{3}{c}{ Industri Barang Konsumsi } \\
\hline Model & $\begin{array}{c}\text { Adjusted R } \\
\text { Square }\end{array}$ & Keterangan \\
\hline
\end{tabular}




\begin{tabular}{lll}
\hline & Variabel profitabilitas, \\
& & likuiditas, struktur aset, \\
& ukuran perusahaan, \\
& pertumbuhan penjualan \\
berpengaruh terhadap & struktur modal sebesar \\
& & $83,3 \%$
\end{tabular}

Sumber : Pengolahan Data SPSS (2021)

Berdasarkan tabel diatas, dapat diketahui bahwa variabel dependen industri dasar kimia dalam hal ini Struktur Modal dapat dijelaskan sebesar $38,2 \%$ oleh variabel independen profitabilitas (ROA), likuiditas (CR), struktur aset (SA), ukuran perusahaan (FS), dan pertumbuhan penjualan (GS). Hal itu terlihat dari nilai Adjusted $R$ Square sebesar 0,382 . Sedangkan sebesar $\quad 61,8 \% \quad$ variabel dependen struktur modal dipengaruhi oleh variabel-variabel lain diluar model penelitian.

Berdasarkan tabel 9 diatas, dapat diketahui bahwa variabel dependen industri barang konsumsi dalam hal ini Struktur Modal dapat dijelaskan sebesar 83,3\% oleh variabel independen profitabilitas (ROA), likuiditas (CR), struktur aset (SA), ukuran perusahaan (FS), dan pertumbuhan penjualan (GS). Hal itu terlihat dari nilai Adjusted $R$ Square sebesar 0,833. Sedangkan sebesar $16,7 \%$ variabel dependen struktur modal dipengaruhi oleh variabel-variabel lain diluar model penelitian.

\section{Pembahasan}

\section{Pengaruh Profitabilitas Struktur Modal}

Hasil pengujian H1a menunjukkan bahwa nilai $-t_{\text {hitung }}$ sebesar $-0,801$ dan $-t_{\text {tabel }}$ sebesar -1,983 dengan signifikansi sebesar $0,425>0,05$. Hasil pengujian $\mathrm{H} 1 \mathrm{~b}$ menunjukkan bahwa nilai - $\mathrm{t}_{\text {hitung }}$ sebesar 1,616 dan - $t_{\text {tabel }}$ sebesar $-1,987$ dengan signifikansi sebesar 0,110 > 0,05. Sehingga dapat disimpulkan bahwa H1a dan H1b tidak berpengaruh terhadap struktur modal. Hasil penelitian mendukung pecking order theory yang menyatakan bahwa perusahaan lebih menyukai pendanaan dari internal perusahaan (laba ditahan dan penyusutan). Keuntungan yang tinggi cenderung memiliki tingkat rasio struktur modal yang rendah. Perusahaan tidak menargetkan tingkat rasio yang rendah melainkan perusahaan tidak membutuhkan dana tambahan dari eksternal

karena laba yang dimiliki perusahaan mampu untuk membiayai kegiatan operasional perusaha an.

\section{Pengaruh Likuiditas Struktur Modal}

Terhadap

Hasil pengujian H2a menunjukkan bahwa nilai - $t_{\text {hitung }}$ sebesar $-6,354$ dan $\begin{array}{lll}t \text { tabel } & \text { sebesar } & -1,983\end{array}$ dengan signifikansi sebesar $0,000<$ 0,05. Hasil pengujian H2b menunjukkan bahwa nilai -thitung sebesar -19,243 dan $t_{\text {tabel }}$ sebesar -1,987 dengan signifikansi sebesar $0,000<0,05$. Sehingga dapat disimpulkan bahwa H2a dan H2b berpengaruh terhadap struktur modal.

Hal ini menunjukkan bahwa perusahaan dengan tingkat likuiditas yang tinggi akan mampu membayar hutang jangka pendeknya dari dana operasional perusahaan. Perusahaan tetap bisa melanjutkan kegiatan operasionalnya dan menurunkan total hutang sehingga struktur modal menjadi lebih kecil.

\section{Pengaruh Struktur Aset Terhadap Struktur Modal}


Hasil pengujian H3a menunjukkan bahwa nilai -thitung sebesar $-4,428$ dan tabel sebesar $-1,983 \quad$ dengan signifikansi sebesar $0,000<0,05$. Sehingga dapat disimpulkan bahwa $\mathrm{H} 3 \mathrm{a}$ berpengaruh terhadap struktur modal. Hal ini menunjukkan bahwa semakin besar aset tetap yang dimiliki perusahaan, maka peluang untuk mendapatkan hutang semakin tinggi. Kreditur akan merasa lebih aman jika memberikan pinjaman kepada perusahaan yang memiliki aset tetap yang besar karena apabila terjadi kegagalan pembayaran bayar maka perusahaan dapat menyelesaikan kewajibannya kepada kreditur dengan jaminan asetnya tersebut. Perusahaan akan memiliki hutang yang lebih besar, hal ini akan meningkatkan struktur modal perusahaan.

Hasil pengujian $\mathrm{H} 3 \mathrm{~b}$ menunjukkan bahwa nilai $t_{\text {hitung }}$ sebesar 0,101 dan $t_{\text {tabel }}$ sebesar 1,987 dengan signifikansi sebesar o,920 > 0,05. Sehingga dapat disimpulkan bahwa $\mathrm{H}_{3}$ b tidak berpengaruh terhadap struktur modal. Perusahaan yang memiliki aktiva tetap yang lebih tinggi dibanding aktiva lancar maka akan mengurangi penggunaan modal asing atau hutang, karena perusahaan menganggap sumber pendanaan internal lebih memiliki risiko yang kecil dan dana tersebut sudah mencukupi kebutuhan dananya. Selain itu struktur aset yang tinggi juga tidak menjamin perusahaan akan menggunakan hutang dan menggunakan aset tersebut sebagai jaminan. Jaminan aset tetap yang tinggi bukan satu-satunya hal yang akan dilihat oleh para kreditur untuk memberikan pinjaman.

\section{Pengaruh Ukuran Terhadap Struktur Modal}

Hasil pengujian $\mathrm{H} 4 \mathrm{a}$ menunjukkan bahwa nilai -thitung sebesar $-5,458$ dan t tabel sebesar -1,983 dengan signifikansi sebesar $0,000<0,05$. Sehingga dapat disimpulkan bahwa $\mathrm{H} 4 \mathrm{a}$ berpengaruh terhadap struktur modal. Semakin besar ukuran perusahaan maka akan semakin tinggi tingkat struktur modal, begitupun sebaliknya. Perusahaan besar mempunyai tingkat kredibilitas yang lebih tinggi daripada perusahaan kecil sehingga

mempunyai akses mudah untuk mendapatkan pinjaman.

Hasil pengujian $\mathrm{H} 4 \mathrm{~b}$ menunjukkan bahwa nilai $t_{\text {hitung }}$ sebesar 0,953 dan $t_{\text {tabel }}$ sebesar 1,987 dengan signifikansi sebesar $0,343>0,05$. Sehingga dapat disimpulkan bahwa $\mathrm{H} 4 \mathrm{~b}$ tidak berpengaruh terhadap struktur modal. Besar kecilnya suatu perusahaan tidak mempengaruhi pendanaan terhadap struktur modal. Dalam penggunaan sumber dana yang berasal dari modal sendiri atau hutang, tentu mempunyai biaya modal yang berbeda dengan tingkat resiko yang berbeda pula. Dalam setiap perusahaan tentu lebih memilih untuk menggunakan pendanaan secara internal sesuai dengan pecking order theory.

\section{Pengaruh Pertumbuhan Penjualan Terhadap Struktur Modal}

Hasil pengujian $\mathrm{H}_{5}$ a menunjukkan bahwa nilai thitung sebesar $-1,893$ dan $t_{\text {tabel }}$ sebesar $\quad-1,983 \quad$ dengan signifikansi sebesar 0,061 > 0,05. Hasil pengujian $\mathrm{H}_{5} \mathrm{~b}$ menunjukkan bahwa nilai thitung sebesar 1,595 dan $t_{\text {tabel }}$ sebesar 1,987 dengan signifikansi sebesar 0,114 > 0,05. Sehingga dapat disimpulkan bahwa $\mathrm{H}_{5} \mathrm{a}$ dan $\mathrm{H} 5 \mathrm{~b}$ tidak berpengaruh 
terhadap struktur modal. Perusahaan yang mempunyai tingkat pertumbuhan penjualan yang tinggi akan cenderung menghasilkan arus kas yang lebih besar sehingga perusahaan tersebut pada akhirnya akan lebih mengandalkan pendanaan internalnya.

Perusahaan cenderung mendapat dana dari penjualan produk sehingga tidak membutuhkan modal dari external. Kemungkinan lain adalah bahwa perusahaan besar yang mempunyai akses lebih mudah ke pasar modal dibandingkan dengan perusahaan kecil belum tentu dapat memperoleh dana dengan mudah di pasar modal. Hal ini disebabkan karena para investor akan membeli saham atau menanamkan modalnya tidak hanya mempertimbangkan besar kecilnya perusahaan, tetapi juga memperhatikan faktor lain, seperti prospek perusahaan, analisa bisnis dan lain sebagainya.

\section{Perbandingan Struktur Modal Pada Perusahaan Sektor Industri Dasar Kimia Dan Perusahaan Sektor Industri Barang Konsumsi}

\section{Berdasarkan hasil darri Uji} Hipotesis menunjukkan bahwa terdapat perbedaan faktor-faktor yang mempengaruhi struktur modal pada perusahaan sektor industri dasar kimia dan perusahaan sektor industri barang konsumsi. Pada perusahaan sektor industri dasar kimia, variabel likuiditas (CR), struktur aset (SA), ukuran perusahaan (FS) berpengaruh terhadap struktur modal dan variabel profitabilitas (ROA), pertumbuhan penjualan

(GS) tidak berpengaruh terhadap struktur modal. Sedangkan hasil uji hipotesis pada perusahaan sektor industri barang konsumsi menunjukkan hasil bahwa hanya variabel likuiditas (CR) yang berpengaruh terhadap struktur modal. Variabel profitabilitas (ROA), struktur aset (SA), ukuran perusahaan (FS), pertumbuhan penjualan (GS) tidak berpengaruh terhadap struktur modal.

\section{KESIMPULAN}

Berdasarkan hasil analisis data dan pembahasan yang telah dijelaskan pada bab sebelumnya, maka dapat ditarik beberapa kesimpulan bahwa untuk perusahaan sektor industri bahan dasar kimia variabel Profitabilitas (ROA) tidak berpengaruh terhadap struktur Modal. Hasil penelitian ini didukung oleh penelitian Desmianti, Paulina, Johan (2017). Variabel Likuiditas (CR) berpengaruh terhadap Struktur Modal, hasil penelitian ini didukung oleh penelitian Nadiah Felinsia, Listiana Sri Mulatsih, Rika Desiyanti (2019). Variabel Struktur Aset

berpengaruh terhadap Struktur

Modal hasil penelitian ini didukung oleh penelitian Baharudin Novenda Putra (2019). Variabel Ukuran Perusahaan (FS) berpengaruh terhadap Struktur Modal, hasil penelitian ini didukung oleh penelitian Tessa Fitria Wulandari (2020). Variabel pertumbuhan penjualan (GS) tidak berpengaruh terhadap struktur modal. hasil penelitian ini didukung oleh penelitian Nadiah Felinsia, Listiana Sri Mulatsih, Rika Desiyanti (2019).

Sedangkan pada perusahaan sektor industri barang konsumsi variabel Profitabilitas (ROA) tidak berpengaruh terhadap Struktur Modal, hasil penelitian ini didukung oleh penelitian Intan Anggita P, Vaya Juliana D (2018). Variabel Likuiditas (CR) berpengaruh terhadap Struktur Modal, hasil penelitian ini didukung oleh 
penelitian Inggrid Liang (2018). Variabel Struktur Aset (SA) tidak berpengaruh terhadap Struktur Modal hasil penelitian ini didukung oleh penelitian Rika, Suhendro, Purnama (2020). Variabel Ukuran Perusahaan (FS) tidak berpengaruh terhadap Struktur Modal, hasil penelitian ini didukung oleh penelitian Liang Natsir (2019). Variabel Pertumbuhan Penjualan (GS) tidak berpengaruh terhadap Struktur Modal, hasil penelitian ini didukung oleh penelitian Khalimatus Sa'diyah (2019).

\section{Saran}

Bagi peneliti selanjutnya yang ingin melakukan penelitian lebih lanjut yang berhubungan dengan struktur modal sebaiknya menggunakan sektor perusahaan yang lebih banyak lagi, supaya hasilnya bisa digeneralisasikan pada sektor perusahaan yang lain.

Bagi peneliti selanjutnya yang ingin melakukan penelitian lebih lanjut yang berhubungan dengan perbandingan struktur modal diharapkan menambah variabel independent seperti Non-Debt Tax Shield, Risiko Bisnis, Ownership Structure Public dan variabel-variabel lain yang dapat mempengaruhi Struktur modal.

\section{Daftar Pustaka}

Barus, A. (2013). Analisis Faktor-Faktor yang Mempengaruhi Profitabilitas pada Perusahaan Manufaktur yang Terdaftar di Bursa Efek Indonesia. JWEM (Jurnal Wira Ekonomi Mikroskil), 3(2), 111121.

Desmianti Tangiduk, P. V. (2017). Analisis Pengaruh Ukuran Perusahaan, Struktir Aktiva, Dan Profitabilitas Terhadap
Struktur Modal Pada Perusahaan Manufaktur Sektor Industri Dasar Kimia Yang Terdaftar Di Bursa Efek Indonesia Periode 2011-2015. Jurnal EMBA, 874-883.

Inggrid Liang, K. N. (2019). Pengaruh Profitabilitas Dan Ukuran Perusahaan Terhadap Struktur Modal. Jurnal Manajerial dan Kewirausahaan, 480481.

Barus, A. (2013). Analisis Faktor-Faktor yang Mempengaruhi Profitabilitas pada Perusahaan Manufaktur yang Terdaftar di Bursa Efek Indonesia. JWEM (Jurnal Wira Ekonomi Mikroskil), 3(2), 111-121.

Irza Nofriani. (2015). Pengaruh Profitabilitas, Ukuran Perusahaan, Pertumbuhan Penjualan, Pertumbuhan Aset, dan Likuiditas Terhadap Struktur Modal Pada Perusahaan Manufaktur yang terdaftar di Bursa Efek Indonesia periode 20102013. Universitas Maritim Raja Ali Haji, Tanjungpinang.

Soehardi, S., Permatasari, D. A., \& Sihite, J. (2020). Pengaruh Pandemik Covid-19 Terhadap Pendapatan Tempat Wisata dan Kinerja Karyawan Pariwisata di Jakarta. Jurnal Kajian Ilmiah, 1(1), 114.

https://doi.org/https://doi.org/10.315 99/jki.v1i1.216

Nadiah Felinsia, L. S. (2020). Pengaruh Likuiditas Perusahaan, Pertumbuhan Penjualan, Ukuran Perusahaan, Dan Profitabilitas Terhadap Struktur Modal Pada Perusahaan Sektor Industri Dasar Kimia Di Bursa Efek Indonesia Periode 2014-2018. ejurnal bunghatta. Putra, B. N. (2019). Pengaruh Asset Tangibility, Growth Sales, Dan Ownership Structure Public Terhadap Struktur Modal Pada Perusahaan Industri Dasar Dan Kimia Yang Terdaftar Di BEI. 
Rika Rizky Ayuningtyas, S. P. (2020). Faktor-Faktor yang Mempengaruhi Struktur Modal pada Perusahaan Industri Barang Konsumsi. Jurnal Ilmiah Universitas Batanghari Jambi, 141-146.

Fadilah, M. A. (2020). Menyoal Kemajuan KEK Tanjung Lesung. Https://Banteninfoshare.Blogspot.Co $\mathrm{m}$.

Unzu, M., \& Djoko, S. (2013). Analisis Pengaruh Cash Ratio, Return On Assets, Growth, Firm Size, Debt to Equity Ratio Terhadap Dividend Payout Ratio : (Studi Pada Perusahaan Manufaktur Yang Terdaftar di Bursa Efek Indonesia Tahun 2008-2011). Diponogoro Journal of Management, 2(3): h: 1-11.

Utami, L. (2013). Pengaruh Return On Assets, Tangibility dan Non Debt Tax Shield Terhadap Struktur Modal Pada Perusahaan Manufaktur yang Terdaftar di Bursa Efek Indonesia.

Wulandari, T. F. (2020). Pengaruh Likuiditas, Profitabilitas, dan Pertumbuhan Penjualan Terhadap Struktur Modal (Studi Empiris Perusahaan Barang Dasar dan Kimia Yang Terdaftar Di Bursa Efek Indonesia Tahun 2015-2019. 